\title{
The Working Women's Forum: Organizing for credit and change
}

Marty Chen

Follow this and additional works at: https://knowledgecommons.popcouncil.org/departments_sbsr-pgy

Part of the Family, Life Course, and Society Commons, Gender and Sexuality Commons, Inequality and Stratification Commons, International Public Health Commons, and the Regional Economics Commons How does access to this work benefit you? Let us know!

\section{Recommended Citation}

Chen, Marty. 1983. "The Working Women's Forum: Organizing for credit and change," SEEDS no. 6. New York: Population Council. 
SEEDS is a pamphlet series developed to meet requests from all over the world for information about innovative and practical program ideas developed by and for low income women. The pamphlets are designed as a means to share information and spark new projects based on the positive experiences of women who are working to help themselves and other women improve their economic status. The projects described in this and other issues of SEEDS have been selected because they provide women with a cash income, involve women in decision-making as well as earning, are based on sound economic criteria, and are working successfully to overcome obstacles commonly encountered. The reports are not meant to be prescriptive, since every development effort will face somewhat different problems and resources. Rather, they have been written to describe the history of an idea and its implementation in the hope that the lessons learned can be useful in a variety of settings. They are also being written to bring to the attention of those in decisionmaking positions the fact that income generating projects for and by women are viable and have important roles to play in development.

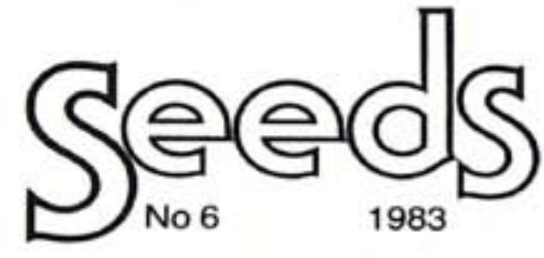

ISSN $073-6833$
Publication of SEEDS is made possible by the support of the Carnegie Corporation, the Ford Foundation, Oxfam-America, the Population Council, and the Rockefeller Foundation, and the Women in Development Office. Agency for International Development.

Statements made and views expressed in this publication are solely the responsibility of the author and not of any organization providing support for SEEDS. 


\title{
The Working Women's Forum: Organizing for Credit and Change
}

\author{
Story by Marty Chen
}

\section{Introduction}

Most of the women who live in the slums of Madras, a large city in southern India, work as small-scale traders and vendors to provide for the needs of their families. Their economic contributions, however, generally have been dismissed by politicians and planners as insignificant or merely supplemental to the earnings of male family members. In actual fact, these women entrepreneurs provide, on the average, one-half of the entire family income.

For years these women went about their work virtually unnoticed by most of society. Then, in 1978, a group of politically and socially active women became disenchanted with traditional approaches to meeting poor women's needs. They began to talk directly to the slum women and soon discovered that most were in business for themselves and that their main concerns were not social problems, but credit - getting money to maintain and expand their businesses.

In response to this need, the Working Women's Forum was created. This pamphlet tells the story of how the Forum came into being and how it has brought together more than 13,000 poor urban women around the issue of credit. It also describes how the Forum not only has provided its members with access to funds, but has expanded to include support services such as child care, education, health and family planning and how the sense of strength and purpose that has grown up among the members is helping them to tackle the political and social problems that affect their lives. 


\section{The Beginnings}

The city of Madras has been called a "rural metropolis." Capital of a large state in south India, Madras (with a population of 2.3 million) is the fourth largest city in India. As it has grown by swallowing up surrounding hamlets, most of its slums are actually villages made up of thatched huts rather than multi-storied tenements. Yet the economy of these areas is no longer rural. Residents now work as day laborers or in petty trade, catering as best they can to the demands of the metropolis for goods and services.

Typically, men of the slum households work as casual laborers three or four days a week. The women generally work at what are termed "other services" such as petty vending and hawking. They usually work every day of the week. On the average, these women earn about U.S. $\$ 20.00$ per month, an amount that often accounts for half of the entire family income. When swings of income of casually employed men are taken into account, along with their typical consumption habits (e.g., frequent outlays for tobacco and liquor), slum families are heavily dependent on the earnings of women for survival. In addition, approximately one woman out of ten is the sole wage earner for her family.

In November 1977, Jaya Arunachalam, a well-known political and social worker, was engaged in flood relief work in Madras. As she went through the affected areas talking to women, she became acutely aware that they were not interested in flood relief or politics. Their main preoccupation was their capacity to earn, and the main problem they faced in trying to earn was lack of credit. In the words of one of Jaya's co-workers (now a vice president of the Working Women's Forum):

Jaya and I went on a fact-finding trip around Madras between October 1977 and February 1978. We found out we were doing wrong by calling women to political rallies

We offered nothing in return. By meeting the women in small groups we found out that each and every woman is engaged in some occupation and indebted to the money lenders. We decided to organize women around economic concerns.

During this period, Jaya took the opportunity of a speech to Bank of India officials to challenge them with the question: "Why aren't you helping poor women?" The banks of India were nationalized in 1969 with a mandate to extend credit to the poor. Yet little, if any, credit had reached poor urban women. The local bank manager, an unusually progressive man, took up the challenge and agreed to meet with and fund credit worthy groups of low income women.

So, with Jaya's encouragement, 30 women petty traders in one slum area organized themselves into a group, met the bank manager and received loans of 300 Rupees (U.S. \$33) each. The group elected a leader and every day she collected money from the members to repay the Bank of India. Within a matter of months it was clear to everyone that the system was working. The repayment rate was 95\%. By April 1978, 800 women had been organized into 40 groups and had received loans. The Working Woman's Forum (WWF) was born.

While credit was the focal point around which the Forum was founded, its leaders recognized the wider social and political forces that limit women's economic opportunities. They therefore outlined broad objectives for the WWF:

- To create an association of women employed in the unorganized or informal sector;

- To identify and address the critical needs of working women;

- To mobilize working women for joint economic and social action by exerting group pressure to demand their social and political rights;

- To improve the entrepreneurial skills of working women through training, material inputs, credit and extension services; and

- To organize support for social services necessary for working women and their families (e.g., child care, education, health, family planning). 

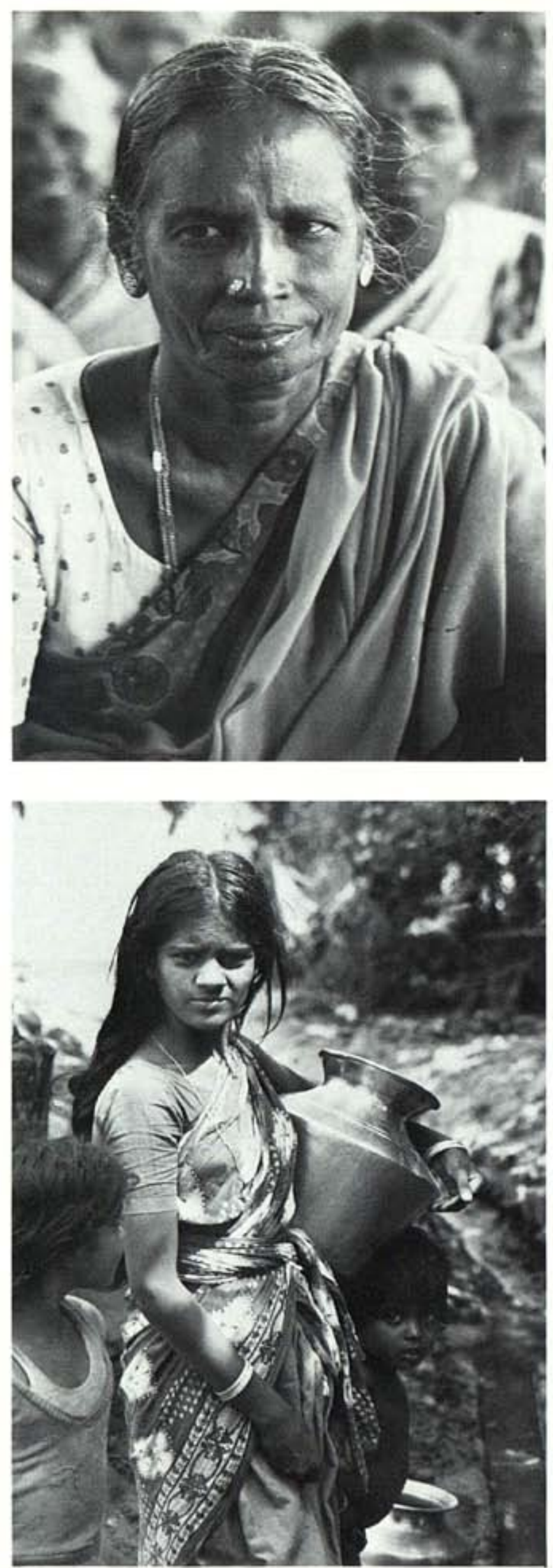

Moreover, in recognition of the potentially divisive factors of caste, religion and politics within Indian society, the Forum's founders adopted certain strong ideological positions. The Forum would be

- Pro Women: exclusive mobilization of women who provide the backbone of family income and welfare.

- Anti-caste and Pro-secularism: support of cross-caste and cross-religious groupings of women, inter-caste weddings and religious tolerance.

- Anti-politics: strict avoidance of involvement in party politics yet mobilization of women around issues affecting women and the poor.

- Anti-dowry: organization of mass demonstrations against dowry, rape and divorce.

\section{The Women}

According to a 1971 census, there were at least 23,000 women in the Madras slums working in "other services." However, it wasn't until the WWF began that much was known about the economic activities of these women. The Forum has identified more than 65 petty businesses and trades operated by its members. The majority fall into four occupational categories: vegetable vending, managing "idly" (snack food) stalls, trading cut cloth, and flower and fruit selling.

Within the various occupations there are even more subtle differences. Some women work at home while some work at a fixed site; others remain mobile. Some women buy wholesale while others buy retail. Some pay cash; some buy on credit. Some women sell within their neighborhoods; others trade at local markets. Some women work part-time while some work long hours or travel great distances to ply their trades each day. Almost all, however, encounter tremendous difficulties in their work. difficulties that almost always revolve around low productivity, low income and perpetual debt. 


\section{Forum Members' Businesses}

(As recorded on loan applications)

Vegetable Vending

Sari/Cut Cloth Trader

Fruit Seller

Junksmith

Greens Seller

Ready-made Garment Sales

Fish Vendor

Firewood Seller

Aluminum Utensil Sales

Incense Maker

Silk Trader

Pandal (ornament) Maker

Plastic Flower Maker

Tea Stall Owner

Pottery Stall Owner

Hay Seller

Snack Shop Owner

Toothpowder Maker

Lime Seller

Salt Vendor
Lungi Trader

Waste Paper Shop Owner

Beedi Roller

Biscuit Maker

Carpenter

Sari Block-Printer

Goldsmith

Stationery Shop Owner

Brush Maker

Groceries Seller

"Idly" (snack food) Shop

Flower Seller

Wire Bag Maker

Tailoress

Cart Loader

Peanut Vendor

Sweet Shop Owner

Mobile Ironer

Snack Food Maker

Cycle Shop Owner
Rice Trader

Meat Shop Owner

Junk Shop Owner

Scrap Iron Shop Owner

Bead Stringer

Wood Box Maker

Bangles Seller

Mat Weaver

Chili Powder Seller

Leaves Stitcher

Gold-Threads Garland Maker

Sweet Stall Owner

Egg Seller

Wood Utensil Maker

Toy Maker

Gunny Bag Seller

Footwear Shop Owner

Coffee Powder Seller

Cardboard Box Maker

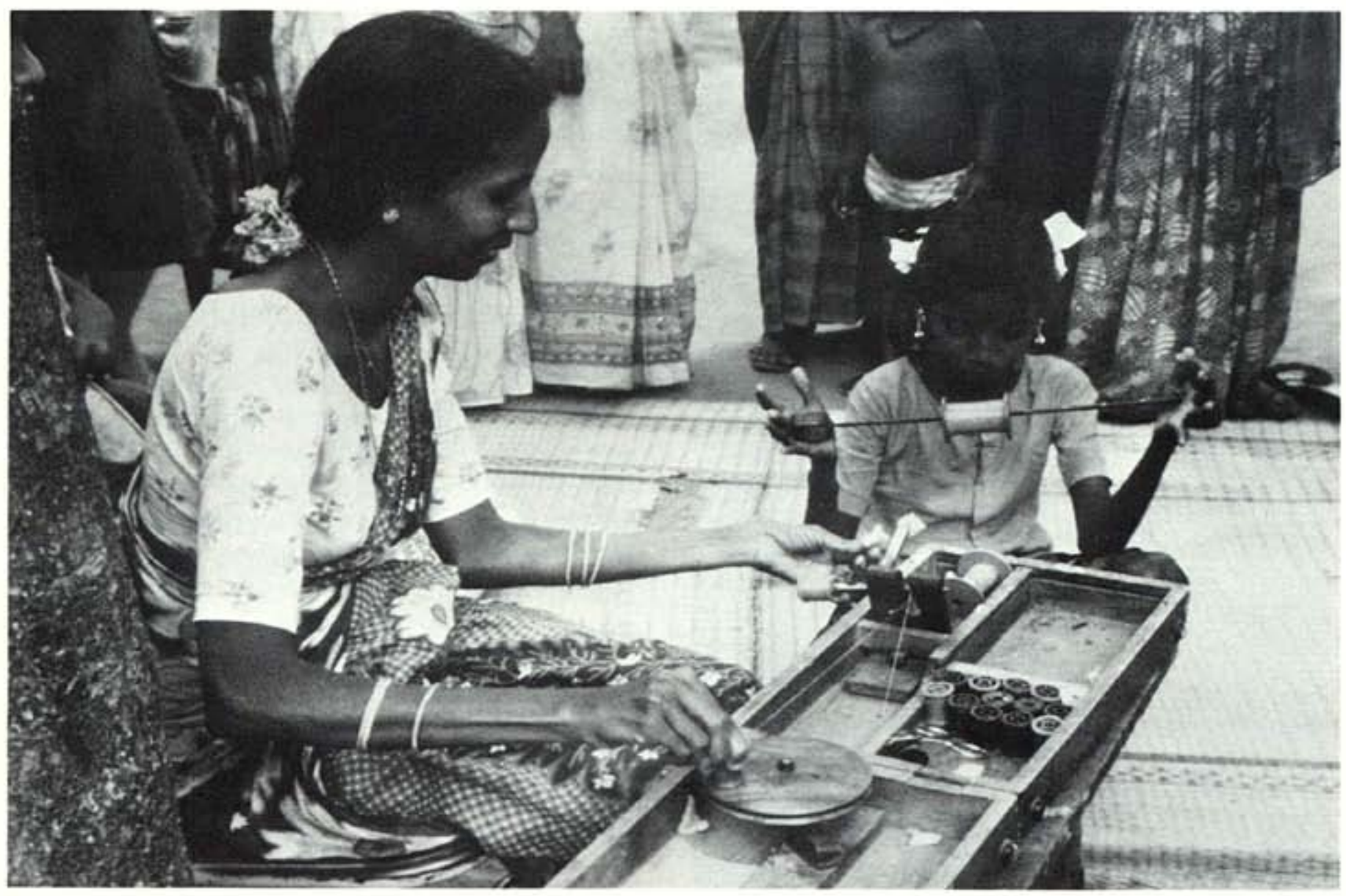


The factors confining women to the lowest levels of trade and business are varied and complex. The structure of the economy and the marketplace favor men who monopolize wholesale markets and the supply of goods and credit. Women frequently are harassed and inhibited at wholesale markets where they are considered high credit risks due to the low volume of their trade. Since expansion of a business requires access to greater supplies and credit, it is obvious why the women's ventures remain small-scale. In addition, many women have been restricted in mobility, due to social customs, and thus have not been able to engage in more profitable activities. Others have limits on the amount of time they can devote to their businesses because of their heavy domestic responsibilities.

\section{Joining the Forum}

The main reason women join the Forum is to gain access to credit. The loans provided through the Forum offer women access to larger sums of money than have been available to them previously from moneylenders and at a reasonable rate of interest. Access to credit has made a big difference in the lives of the more than 7,000 women who, so far, have received loans from the Forum. For example:

Kamala runs a small snack food business from her front yard. She sells steamed rice and lentil cakes in the morning and fried rice cakes in the afternoons. Every week she buys rice and lentils and every night she grinds these staples into flour and prepares the dough which must ferment overnight. Previously, Kamala had to buy her supplies on credit with a daily interest charge. After paying back what she owed with interest, she earned about 50 cents per day. After receiving a loan through Working Women's Forum, Kamala now is able to purchase supplies in bulk, without high interest, and she is earning $\$ 1.00$ per day.

In Kamala's neighborhood there are at least 100 women who operate similar snack food businesses. Countless other women

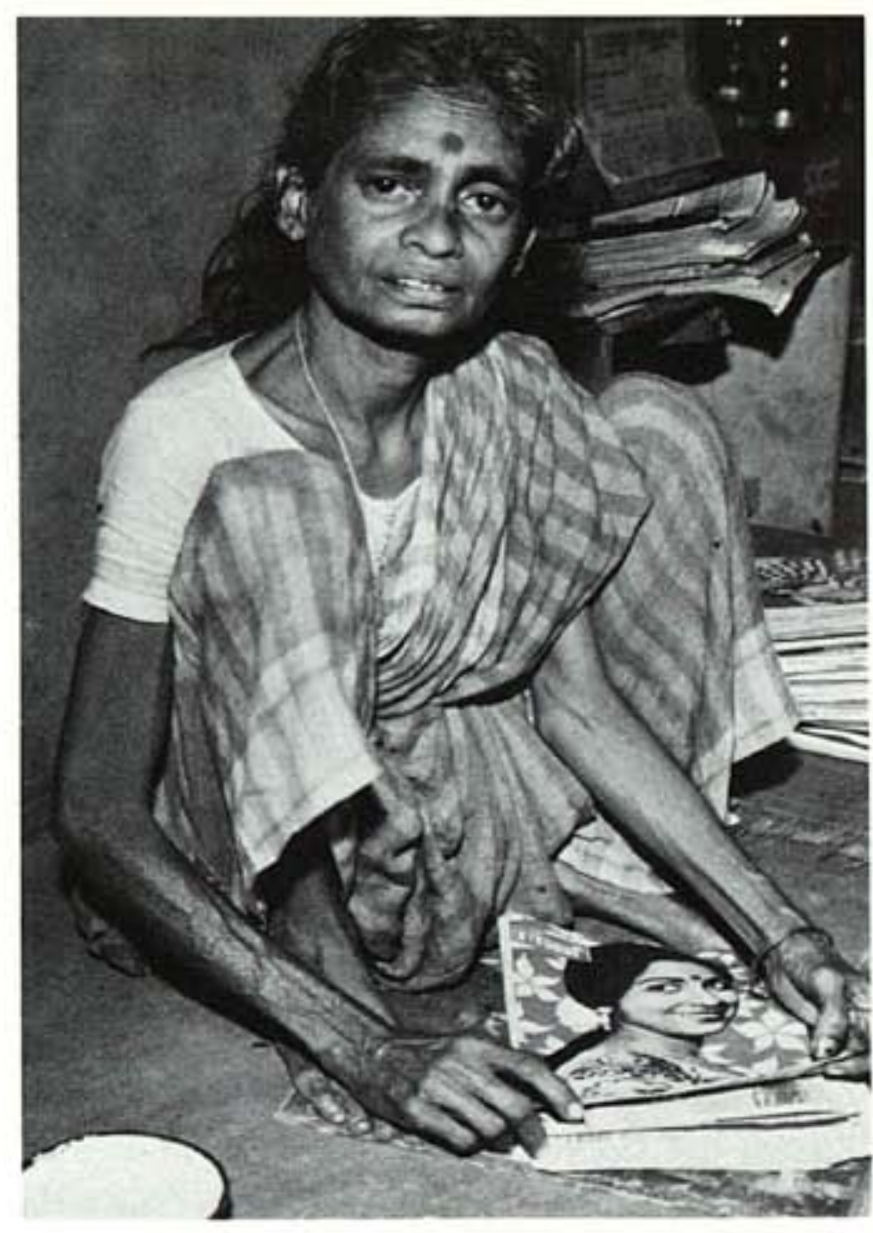

are vendors of vegetables or kerosene, or they work at tasks such as mercerizing thread (treating with caustic alkali solution to strengthen and make it more receptive to dyes) or rolling charcoal-and-dung balls used as cooking fuel. Some slum women work piece-rate for large traders while others work as wage laborers. In some households, both husband and wife work at the same business. In the majority of cases, however, the women have their own, independent sources of income.

\section{How the Forum Operates}

Despite its large membership, the Forum's organization is fairly simple. Perhaps its most noteworthy aspect is that, with the exception of Jaya Arunachalam, its founder-president, all the executive and administrative staff have been recruited from the Forum's membership, i.e., poor, often illiterate, women from slum neighborhoods. These women have been selected either because of previous organizing expe- 
rience with political parties or on the basis of demonstrated organizing potential. Generally, staff are not given any formal leadership or management training but learn onthe-job, through experience.

The principles of political organizing were applied by the Forum staff in developing their organization. The grassroots approach is emphasized. There is at least one local organizer for every 1000 people, working right within the community. And there is continual emphasis on organizing new groups and developing new leaders so that the source of the Forum's direction is always its grassroots membership.

The basic structure of the organization was developed around the requirements of the credit program. (See Appendix I for an outline of the organizational structure.)

\section{The Credit Program - How It Works}

When the Government of India nationalized the banks, it prescribed a differential interest rate (DIR) of $4 \%$ per annum for the

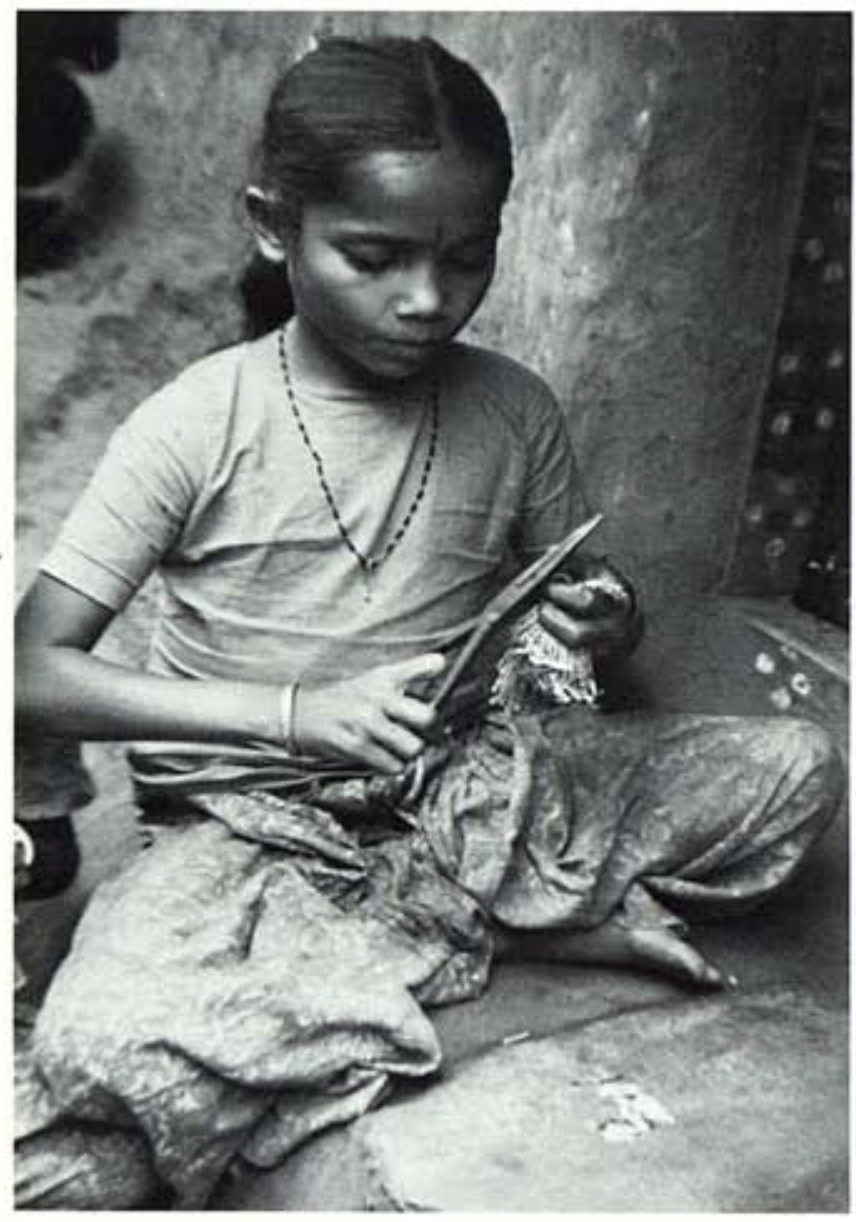

"weaker section of society." This program is commonly referred to as the "small borrower" scheme. Although in theory the working women of Madras were entitled to receive the DIR, they in fact rarely if ever were. able to obtain credit from banks. Moneylenders or next of kin were the only sources available to them, generally at $120 \%$ per annum! When Jaya Arunachalam challenged the bankers to do something to help poor women, they had to admit that they only had thought of the DIR scheme as applying to poor men.

The women themselves said that the banks were reluctant to extend credit to them because they did not recognize the women's petty trading activities as legitimate businesses and they did not like to finance a large number of very small loans. Banks also require male co-signers on loans to individual women. In addition the women were reluctant to approach banks because they found them very formal and impersonal, rarely willing to assist illiterate borrowers with the large number of forms that must be completed to secure a loan.

In order to circumvent these problems, the Forum's founders decided to organize the potential borrowers into mutualguarantee loan groups which, through an efficient administrative process, would link them to the nationalized banks.

Neighborhood Loan Groups. The key element in the Forum structure is the neighborhood loan group. Anyone interested in joining the Forum must become a member of one of these groups. Each group is made up of 10-20 members, all women from the same neighborhood. Most groups are formed by word of mouth. Forum members and staff continually hold group meetings and discussions to acquaint women with the program. A usual pattern is for a potential leader to approach a Forum staff member. She then is told to bring together a group of 10-20 women and explain to them how the Forum works. When a sufficient number have committed themselves, they elect a group leader. On some occasions Forum staff will approach a woman and encourage her to put together a group. 


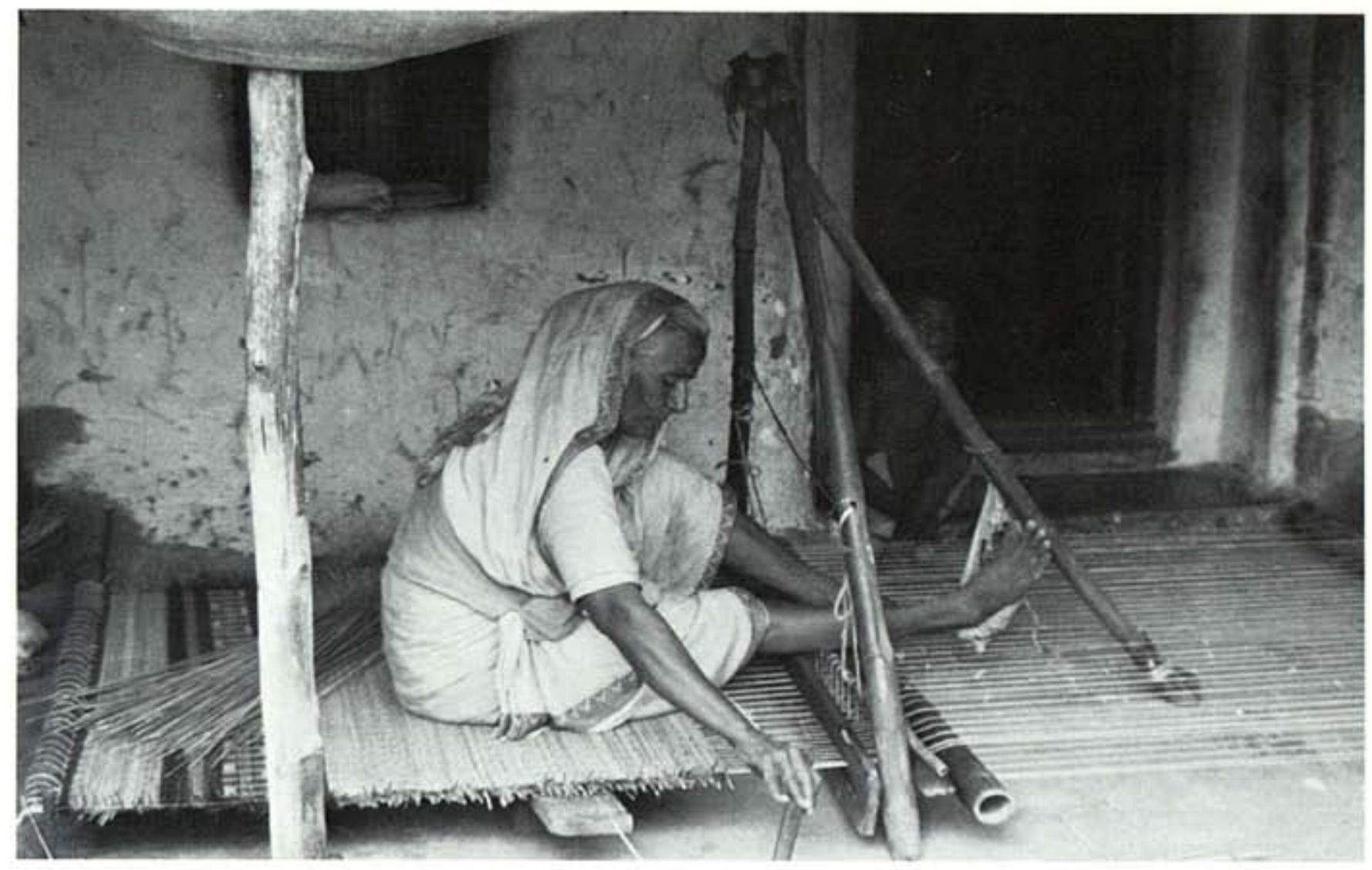

Once a neighborhood group is organized, it is registered with the Forum. Each member then files an individual application form and pays a membership fee. A woman may become either a full member or an associate member. Full members pay an annual fee of 12 rupees (\$1.33) which entitles them to participate in the credit program. Most women become full members. Associate members pay half the annual fee and participate only in the Forum's noncredit activities (described below).

The membership requirements are simple: a member must attend group meetings regularly, repay loans consistently, and act as a mutual guarantor for the loans of all group members.

Loan Procedures. Once registered, group members may apply for loans. All members apply together at one time. The group may apply for a second round of loans only after the first loans have been repaid in full. The following steps are involved in applying for a loan:

\section{Review of Credit Worthiness}

- The group leader assesses the need, capacity and productivity of individual members before recommending them to the WWF area organizer for loans.

- Group members review each other's ability to earn before offering their mutual guarantee or security.

\section{Loan Application}

- The group leader refers the member-applicants to the area organizers.

- The group leader, member-applicants, and WWF area organizer go to the Forum's office to file the application,

- The member-applicants fill out a loan application (a simple, one-page form) at the Forum's office with the assistance of the group leader, area organizer, general secretary and loan officer.

- The general secretary and loan officer sort the applications and submit them to the respective local bank branches (at present, the Forum is working through eight local branches of the Bank of India). 
- The general secretary and loan officer inform the area organizers as to which local branch has received the individual applications.

\section{Loan Disbursement}

- The area organizers contact the respective local branch to determine on which date the individual loans will be disbursed.

- The area organizer takes the members to the bank on the stipulated date.

- The members fill out two forms at the bank under the supervision of a bank official; the bank official in turn fills out additional forms (at least half a day goes into processing and receiving loans for each group).

\section{Loan Repayment}

- The loans are taken at a 4\% DIR interest rate.

- Loans are taken on a ten-month repayment schedule (ten monthly installments were preferred to twelve in the interest of keeping the mathematics simple).

- The group leader is responsible for collecting and depositing the monthly repayments. She collects on a daily or weekly basis, depending on the preference of each individual member.

- The group leader must deposit the repayments before a stipulated date each month.

- The area organizer is called in to help collect repayments only in the case of default.

\section{A Woman's Perspective on Credit}

The nationalized banks stipulate that loans should be invested only in what they call "productive" purposes (i.e, commercial or business investments) and most of the money the women borrow does go directly into their businesses. However, a majority also divert some portion of their loans to meet critical consumption needs (food, clothes, utensils or household repairs) or to repay debts. As the intermediary between the working women and the banks, the Forum has been able to develop a flexible repayment system that takes into account the realities of poor women's lives.

For example, the Forum has developed a broader definition of productive and economic activities that includes housework and childcare. It also has recognized the need to borrow to purchase staple items or to meet health expenses. In addition, it recognizes social consumption patterns that reflect vital elements in the Indian culture such as marriage or religious festivities which are perceived by the women to be social and economic investments. The Forum also recognizes the importance of repaying debts to moneylenders and suppliers since this eventually will enable a woman to make more money available to her business. It also will keep her on good terms with the moneylender who still remains a reliable source of funds in an emergerscy.

It is the Forum's loan officer who ultimately decides who gets a loan and who may default or adjust a repayment schedule. A number of reasons for rescheduling might be viewed as highly unusual within the banking community, but are very realistic in terms of the lives of poor women. These include:

- Unusual or unforeseen fluctuations in supply or price of goods, such as when monsoon rains flood streets and houses and affect the supply and prices of perishable goods, transportation and communication.

- Marriages. In reality this is an economic transaction since the bride's family must invest a suitable amount to secure a good marriage and both families must invest considerable time, energy and cash in preparing for the various wedding ceremonies.

- Childbirth. Although women return to work within days (even hours) of delivery, there are still costs (e.g., 


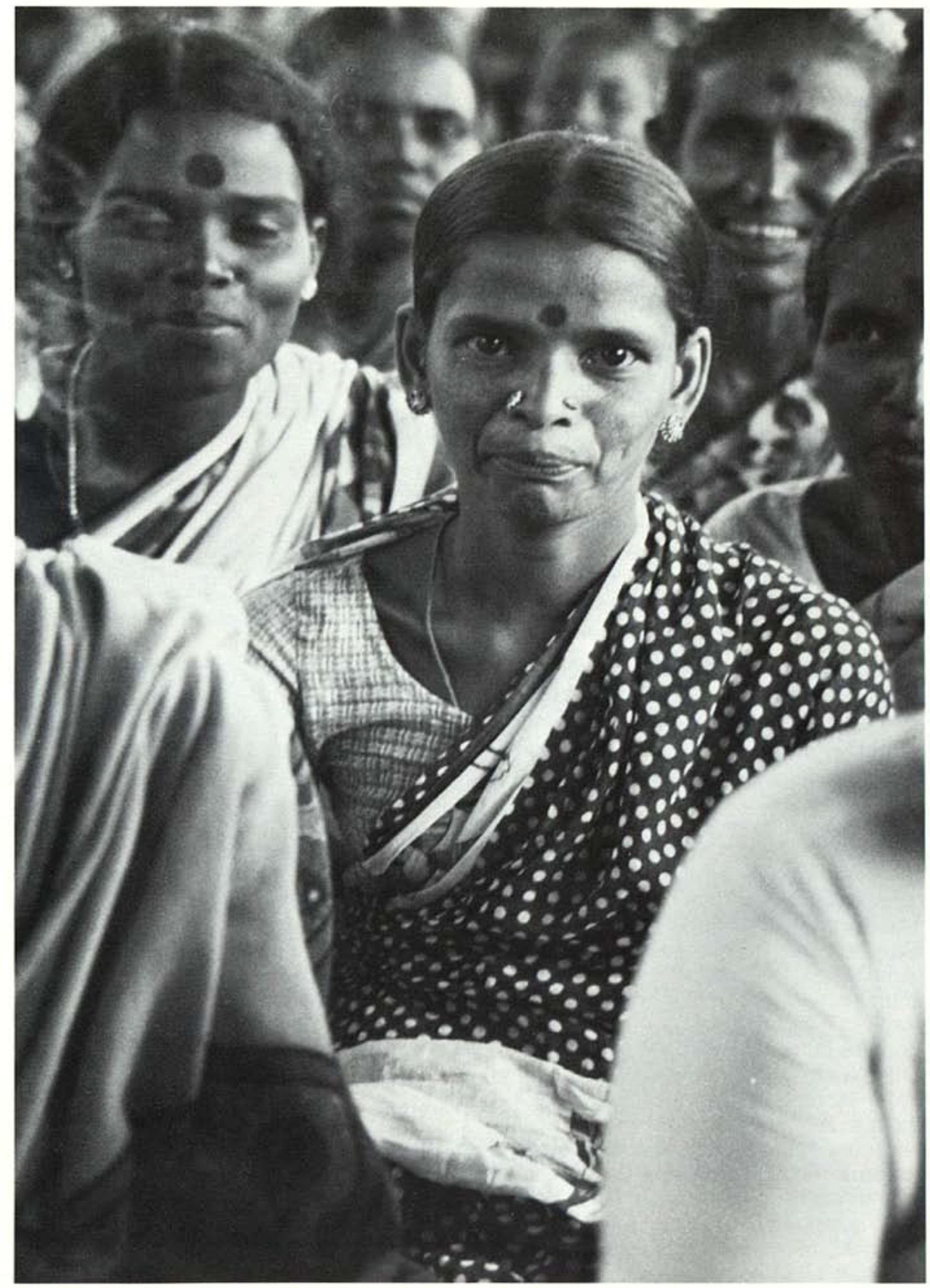


midwife) and loss of time (breastfeeding, childcare) to be taken into account.

- Medical Procedures. When women must visit a health facility for an extended period (e.g., major illness, sterilization, etc.) or have a very sick child or family member, there is time lost from work.

- Accidents and Disasters. Fire and floods are frequent calamities affecting slum dwellers that can wipe out a woman's entire stock and savings.

- Festivals. Religious rituals are an important part of the women's lives. They not only provide a source of inspiration and hope, but are often their only opportunity for recreation.

When a member has a "good reason" she can postpone one or two of her payments. Most "good reasons" have a seasonal pattern and a flexible program like the Forum is able to take these into account. In the case of death, the banks will recognize the default as legitimate. However, if an elderly woman wants to joint the credit program, she must have an heir guarantee her loan.

Of course, there are always a few who default for no good reason. When the Forum first began, some defaulters would try shifting to another group to try to get a second loan. Now, the Forum returns the defaulter's fee and terminates her membership. Only those who are judged to be genuine selfreformers are given a second chance at membership. Occasionally a dishonest group leader will attempt to divert the repayments of others to her own use. However, once the bank notice comes to the group's attention, they can bring pressure on the leader to make the proper payment. The whole system works on the basis of peer pressure. The group exerts pressure on individual members to repay loans because their own credit worthiness rests on the group's repayment record. Likewise, they can exert pressure on the leader to carry out her responsibilities honestly and efficiently.

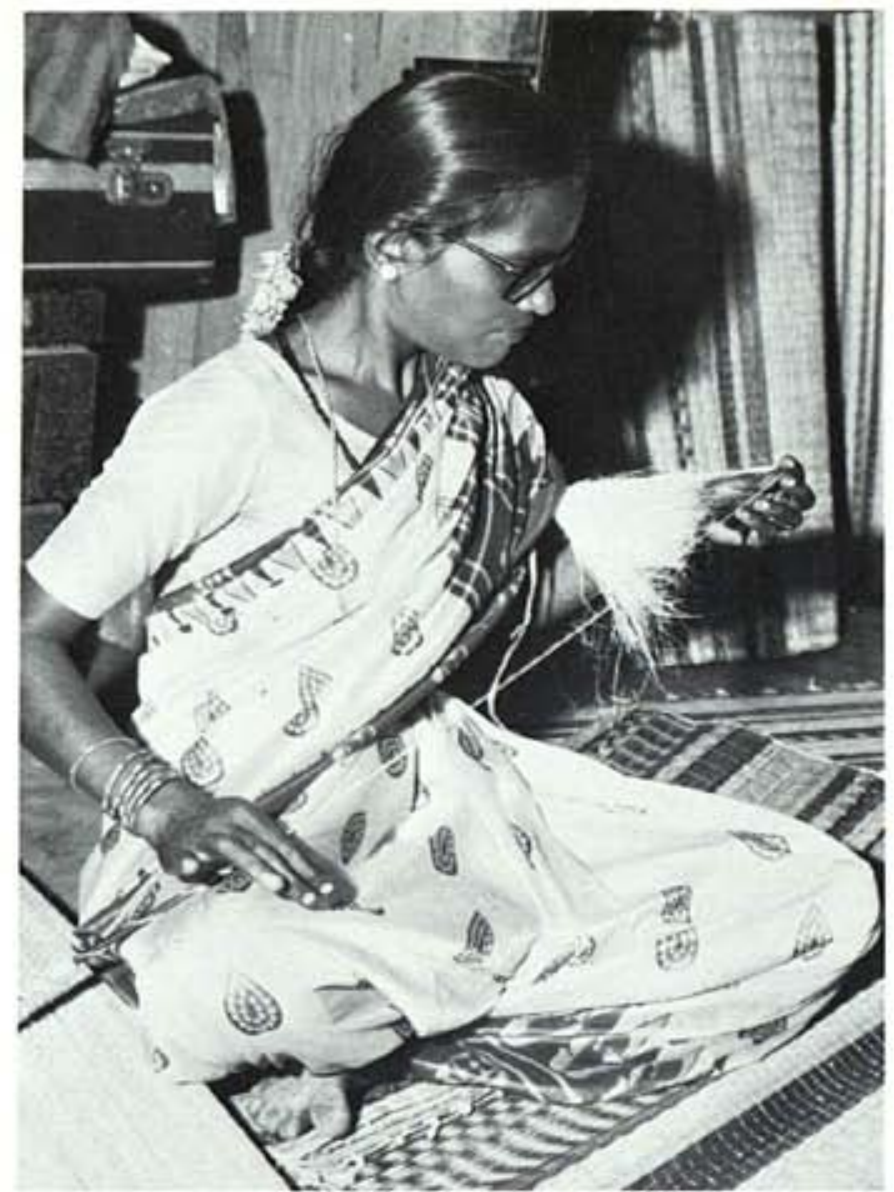

\section{Results of the Credit Program}

The loan program has had a very tangible impact on the women's businesses and on the welfare of their families. An estimated 2,800 new jobs or businesses have resulted from the program and earnings have increased an average of $50 \%$ in existing enterprises. It also has assisted many women to expand and diversify their economic activities.

Previously Ramanji was a vegetable vendor. She used her first loan from the Forum (Rs. 100 or \$11) to reinvest in her business. She used her second loan (Rs. 200) to cancel the debts she had accumulated in the vegetable business. With her third loan (Rs. 300) and Rs. 500 borrowed from another source she invested in a new business: the manufacture of cloth brushes used to polish metal. She now employs four other women in this business and has given up vegetable vending to devote full time to brush-making. She now wants to take out another loan of Rs. 1000 to purchase a sewing machine. 
Ramanji's husband is a semi-permanent painter. Her three sons are unemployed. Only Ramanji brings in a steady, daily income.

Still other women, through the credit program and moral support provided by the Forum, have started businesses for the first time.

Before joining our Forum I used to work as a coolie (day laborer) at building sites. At that time I met Pattammal (a WWF leader). She inquired about me and I told her all my difficulties. Then she suggested I enroll myself as a member of the Forum and that she would get me a loan to start a small business. I enrolled, got the loan and started a cloth goods sales business.

\section{Murugammal, General Member}

The women themselves report that the most basic indicator of the success of the program is that they are eating better; families that often had to get by on one meal a day now can eat twice and are consuming a better quality and variety of foods. A study* of how 300 loan recipients invested their extra earnings revealed the following priority of expenditures: food, clothing, savings, avoidance of the moneylender, household durables, medicines, improved male education, household repair, improved female education, and jewelry (for Indian women, investment in jewelry is not a matter of vanity but a primary means of saving for future security).

Most women report an increased feeling of economic security since joining the Forum. For the first time, their economic activities are on record with an established financial institution and they are being recognized for their work. It is also the first time poor women have been able to get bank loans without a male guarantor or signatory.

We have totally eliminated male members of the family as guarantors. Women have taken on full economic roles.

Jaya Arunachalam

-Hilde Jeffers. Organizing Women Perry Traders and Producers A Case Study of the Working Women's Forum. Madras. WWF

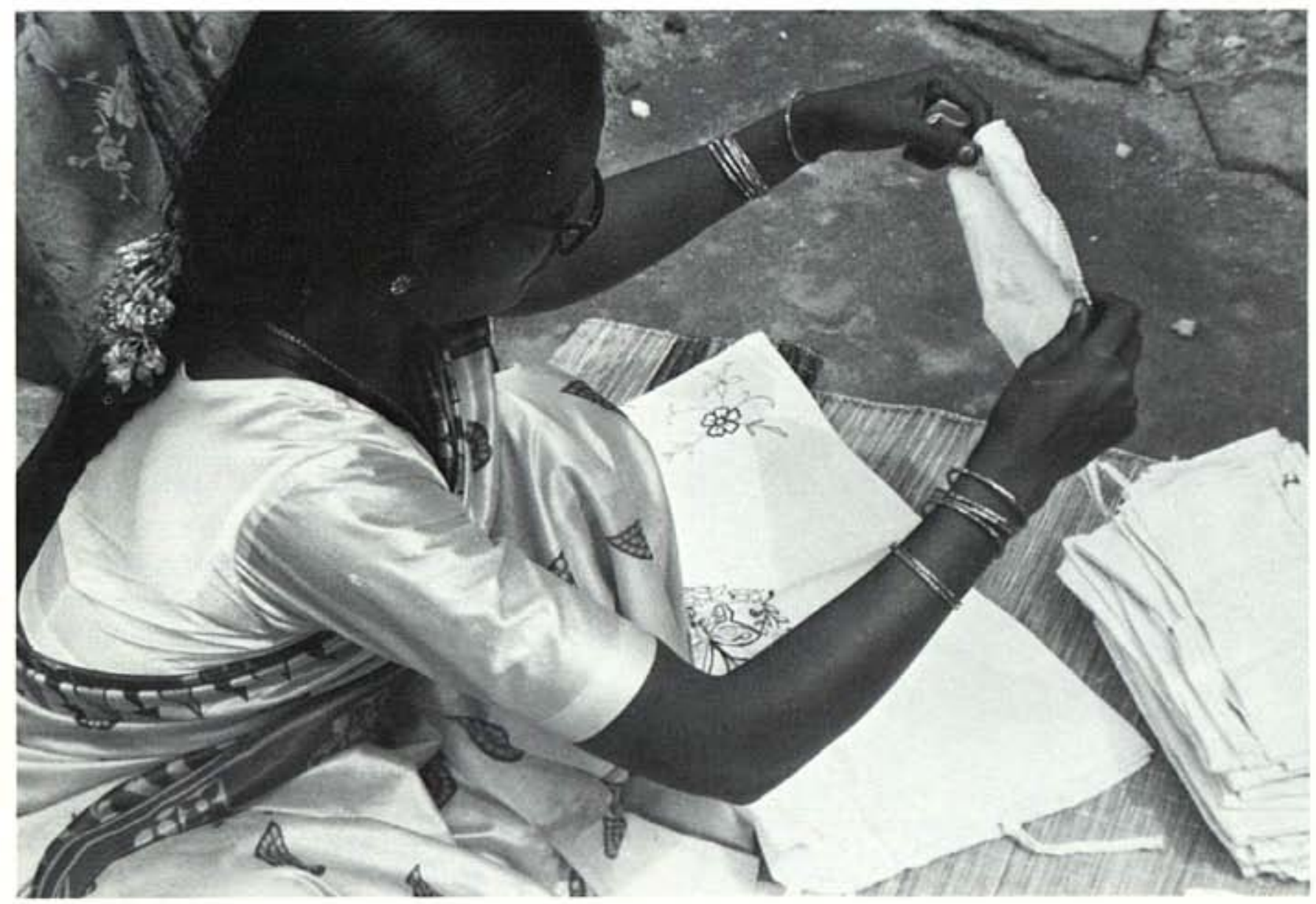



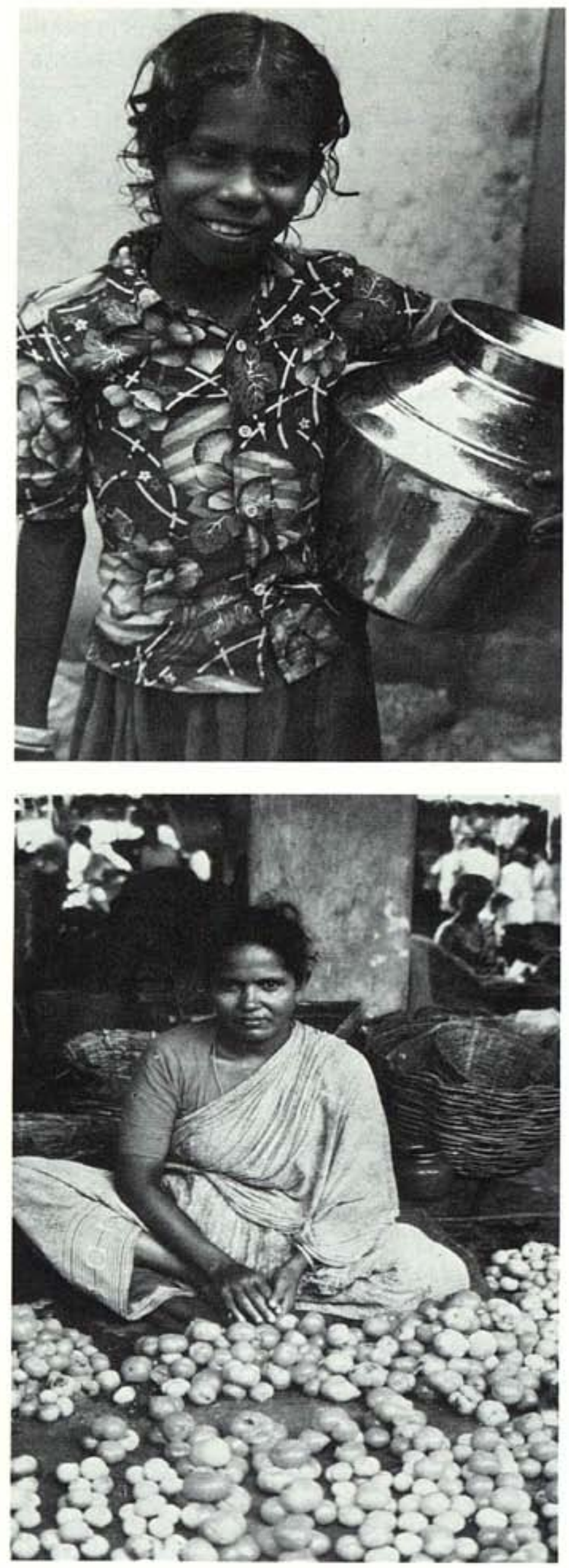

\section{In Support of Women's Economic Roles}

The credit program is seen by the Forum staff as one stage in a larger strategy for social change, a strategy which shifts gradually from addressing basic economic needs to tackling the related and often more complex social and political problems of working women. Now that neighborhood credit groups exist, it is possible to move on to other activities and programs.

Support Services. A number of social service projects have been developed. Many have been initiated by general members. In some slum communities, several loan groups have joined together to set up programs such as:

Day Care Centers. The Forum considers day care to be an essential service for working women. Ten day care centers have been opened by Forum groups. Literate general members are selected and paid to serve as teachers. They are supervised by the group. A typical day care center is described by one of the teachers:

Thirty-six children, between the ages two and five attend. They stay at the center from 9:00 a.m. until 3:00 p.m. One maid (paid by the Forum) and one mother (on rotation) help me clean, oil and comb the hair of the children. After prayers and attendancetaking, I teach the children Tamil (the local language), English and math. We feed them a nutritious, low cost lunch consisting of lentils, vegetables and rice or greens, tomatoes and rice plus biscuits and snacks. The mothers help cook the midday meal. The children sleep after lunch.

Often these centers are no more than a modest thatched shed. Finding space for more centers has been difficult and is the main reason why this activity hasn't been expanded further. In addition to finding more space, the Forum recognizes the need to develop a higher quality of care and instruction and the need to provide more toys and other equipment. 


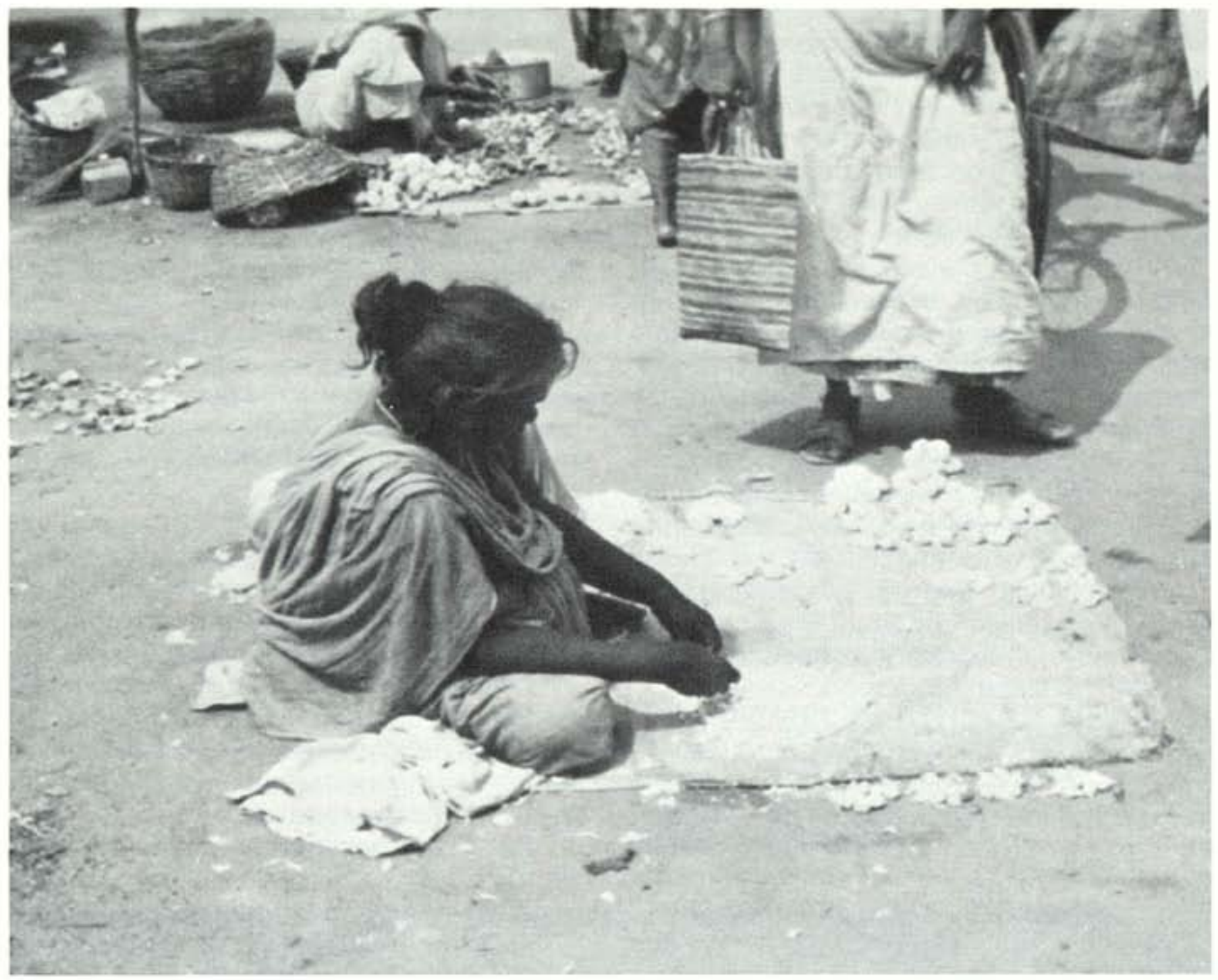

Night Clases. Twenty-two evening classes for primary and middle school children (35-50 boys and girls per class) have been opened. Again, literate general members are hired as teachers. They are paid and supervised by the group. The classes are designed to improve the children's academic performance and prevent them from dropping out of school. The teachers help children with homework assignments from their regular school and coach them in weak subject areas. There has been a considerable improvement in the school performance of children attending these night classes.

Skills Training. The Forum has started ten training centers to expand and upgrade members' skills. These centers focus on the unemployed and those engaged in extremely low paying work. Upon completion of the training course, women who wish to seek jobs in local industries (particularly the ready-made garment industry) are given certificates of completion. In the future, the Forum hopes to organize graduates into cooperative production units.

Health and Family Planning. In 1980, the Forum launched an experimental management training program in health and family planning. The goal not only was to improve health within the community but also to develop the leadership and management skills of a cadre of Forum members who could then assume greater responsibility within the organization. 
Sixty women have been trained thus far as field workers. They disseminate information on health, nutrition and family planning to families living in their own communities. All trainees must have at least minimal literacy in order to record data. They are given a special training course and earn $\$ 18$ per month for their work.

The Forum considers the family planning program to be an essential component in improving both the health and economic status of the community. To quote one staff member: "The family planning program was an outcome of the realization that incomegeneration and large families do not go together. Many of the loanees face serious difficulties in raising the quality of life for their families due to their sheer size."

The health and family planning program has had an important impact on the community. One trainee describes the situation in her neighborhood:

The slum dwellers here never know to talk to others. But after joining in WWF, I have come to know many things. Previously the slum children were not shown (i.e., kept hidden) when the corporation (public heaith) people came for vaccination. After our training each of us were given 100 houses to take care of. Now that we ourselves have explained the advantages of vaccination, they bring out the children and have the benefit.

$$
\begin{array}{r}
\text { Marayammal, Health \& Family } \\
\text { Planning Worker }
\end{array}
$$

Social Action. Organization and mobilization are the essence of the Working Women's Forum. The Forum has utilized the strength of the local loan groups to unite the women on issues that traditionally might have divided them (caste, religion, party politics). As a group they also feel more confident to confront political forces that might be threatening to them as individuals (civic authorities, police, middlemen, moneylenders, wholesalers). Some activities undertaken by the Forum to help strengthen the cohesiveness of the local groups include:
Inter-Caste, No Dowry Marriages. Although discrimination on the basis of caste is illegal in India, centuries old customs die hard. For women of low caste, this is an added burden to bear besides poverty. One member describes her own situation.

I never used to talk to anybody in my school days and others used to say that I was a Harijan* and low caste. . . I even used to tell my father and cry, saying: "Some people differentiate and talk low of me." My father used to say: "We have more love and affection, they only have money." After joining this Forum, we do not have caste differences that much.

Another old custom that has been illegal for decades but still persists is dowry. The WWF has been able to strike a blow against both of these debilitating customs through the promotion of inter-caste marriages. Some 300 WWF members have been married in mass ceremonies conducted without dowry and at low cost. Many of the marriages simply serve to legitimize long-term common law unions. They therefore provide both legal security and social status for the women. The mass weddings are attended by government officials and provide the Forum with an excellent opportunity to publicize its anti-caste and anti-dowry position and to put pressure on the government to institute the economic incentives for intercaste marriages that it has promised.

Lobby for Public Goods and Services. The Forum has assisted members in lobbying (and on occasion fighting) city officials on vital issues such as: protected pavement or stall space for women vendors; construction of thatched sheds in markets for women vendors; construction of toilets for women in markets and other public

\footnotetext{
"Harijan means "children of God" and is the name Gandhi gave to those of the lowest social class, who had generally been called "untouchables," as an attempt to improve their status.
} 
places; building and repair of roads, latrines and houses in slum areas; protection from police harassment.

\section{Impact}

The mobilization of the women around social and political issues as well as credit has resulted in perceptible changes in their attitudes on matters ranging from caste to family planning. Today, the majority of general members oppose dowry and favor inter-caste marriages and they are even more strongly convinced that women should play active economic roles. Most favor women working outside the home. There also is a growing realization that it is possible to have some control over their lives, including their fertility.

Most Forum members report that they have gained greater respect, power and decision-making authority not only within their own homes but within their communities as well. They recognize that their capacity to bargain and to bring pressure for their rights increases as the degree of their solidarity increases.
Many of the women are illiterate; some are educated but most are very poor. Through the organization they have gained some status - new respect - in the community ... Through the discipline of the organization, we have seen a great advancement for women.

\section{Kala, Family Planning}

Supervisor

The neighborhood loan groups, then, are more than a mutual gurantee system for credit. They also provide a social network for the members. Often, the group is the first opportunity women have had to establish relationships outside their families. It offers women a base where they can air problems and seek solutions. Through these groups the Forum has been able to tap and develop a vast reserve of dormant "woman power."

\section{New Developments}

Through the WWF, the nationalized banks to date have disbursed over 7,000 loans to poor women. The banks now view the group guarantee loan system as highly favorable and, with a repayment rate of over

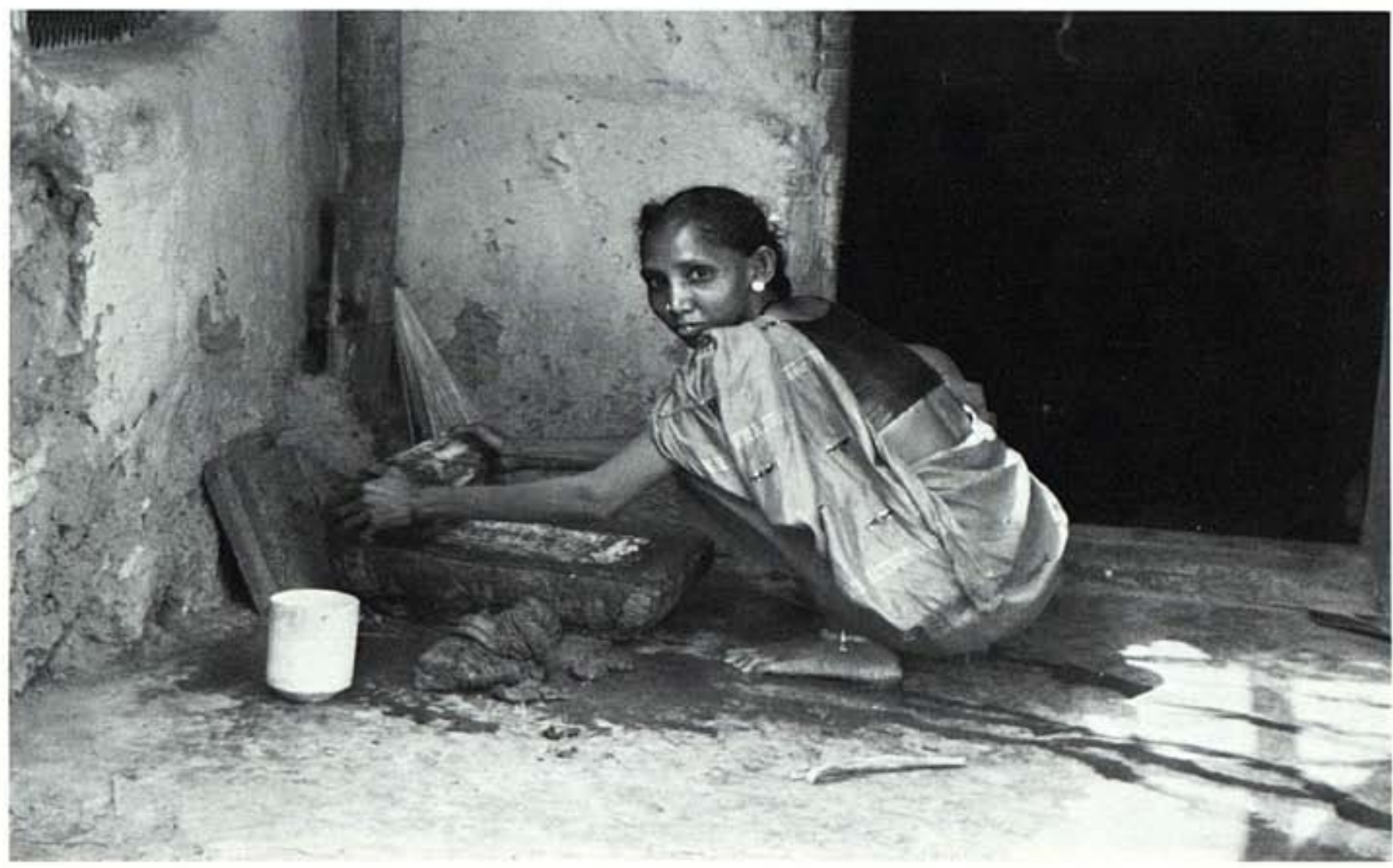


$90 \%$, are expanding the program. However, the Forum still experiences some chronic difficulties in working with the nationalzied banks:

- Delays in receiving loans due to the high volume of very small loans often means that some women must continue to rely on moneylenders while waiting for their loans;

- Inflexibility in disbursement and repayment schedules; the Forum has been able to introduce the flexible repayment procedures noted earlier only by absorbing the cost itself.

The Forum therefore decided to build on its own experience managing the initial credit-referral program and open its own bank. It opened the Women's Cooperative Credit and Social Service Society in 1981. Selected Forum staff were given special banking training and the borrowers with the best credit ratings from among the general membership (5,000 out of the 13,205 members) were invited to become share- holders at the cost of 20 Rupees $(\$ 2.30)$ per share. Each shareholder is entitled to a credit line ten times the value of the shares she holds. In time, the Forum hopes the Society will provide not only credit but technical and marketing assistance to shareholders as well.

National Union of Women Workers. In 1980, the Forum began to work with rural as well as urban women. With the assistance of a government program called Labto-Land, Forum staff organized a scheme designed to disseminate technological know-how to women in rural areas. WWF helped 400 landless women to acquire livestock and receive training in animal husbandry. The Forum also helped organize and negotiate credit facilities for rural fisherwomen and lace makers.

As a result of their work WWF staff recognized the potential power of organizing women along occupational lines (not only on the basis of neighborhood ties) to increase their negotiating power. They therefore inaugurated the National Union of

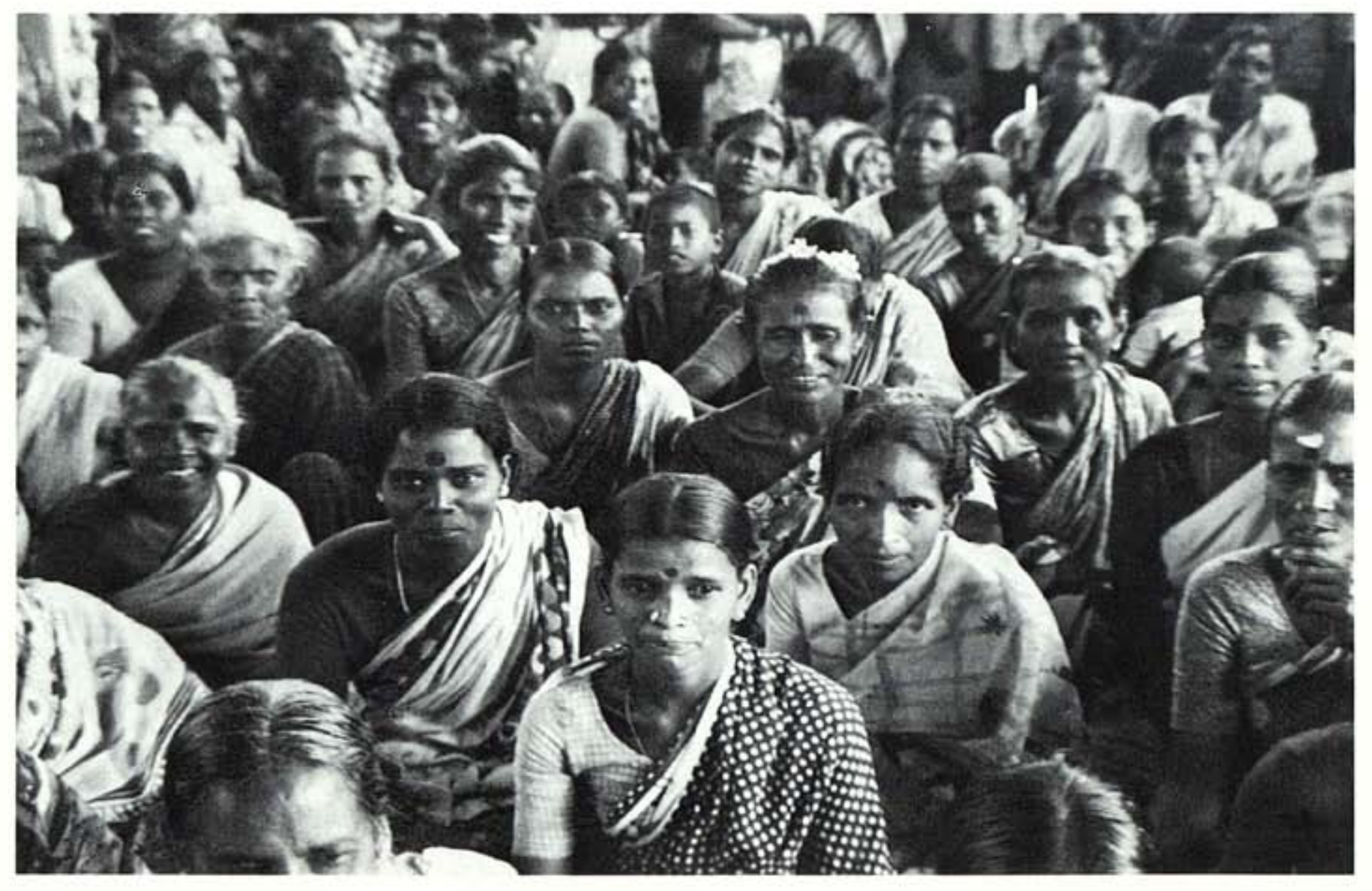


Women Workers in May 1982, to provide a legal umbrella for expanding the "unionizing" work of the Forum and to publicize the need to unionize women who work in the informal sector (i.e., those outside factories and workshops).

\section{Future Directions}

When asked to reflect on the future directions of the WWF, Jaya Arunachalam had many thoughts and plans. In terms of general strategies, Jaya sees a need for:

- Additional social services to provide women the necessary backup and support for their economic roles;

- More complete and competent technical services to increase the efficiency and productivity of women's enterprises;

- Alternative marketing systems to transform women's petty trading businesses to higher commercial status;

- Increasing bargaining power and strengthening pressure groups to demand greater access to and control over government goods and services.

In terms of specific activities, Jaya and her staff already have proposed the following:

- Cooperative production units to provide more secure and productive employment, especially for unemployed women and those engaged in extremely low-paying work;

- Wholesale marketing depots to supply trade items (saris, cloth goods, readymade garments) and raw materials to women at the lowest possible wholesale prices; and

- A wholesale marketing network to link the marginal and landless farmers within a 25-mile radius of Madras to women traders within the city and, thereby, to eliminate the middlemen.

\section{Lessons Learned}

1. Very small loans (as low as $\$ 10$ ) can be made to large numbers of women

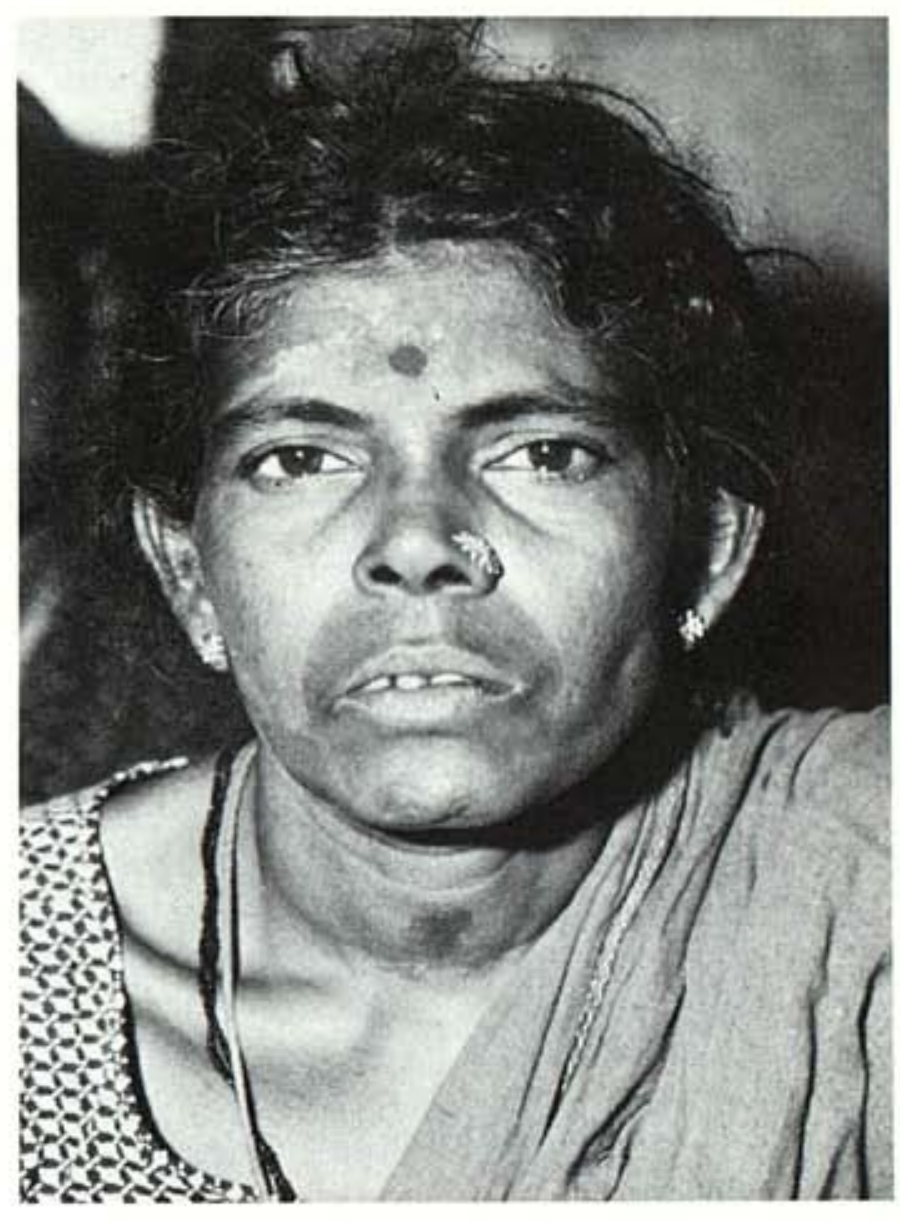

borrowers by commercial banks at a repayment rate of over $90 \%$. To do so does not necessarily require high levels of overhead, supervision or technical assistance.

2. A loan program can be built and expanded quickly if built around small groups of women (10-25) who share neighborhood, occupational or other ties. When a loan program is linked to formal financial institutions, loan procedures need to be reworked so that the review of credit worthiness is undertaken by peers and the women's micro-enterprises can serve as collateral. Repayment also should be structured around peer pressure.

3. It is preferable to begin a program by supporting women's existing economic enterprises rather than attempting to train them and create new jobs. Technical assistance, skills training and enterprise development can be added later. 
4. A project to help poor women should begin with activities that produce quick, tangible results. It is best to address their most immediate and concrete problems first. Additional activities then can be sequenced, moving from basic economic needs to more complex social and political constraints. Only those issues most often discussed and most adequately analyzed by the women themselves should be addressed.

5. Program planning should not follow any definite blueprint. Requirements for staffing and financing should develop out of an evolving program.

6. A program for women is more likely to succeed if it adopts at least two elements: (a) a strong, pro-women ideology to instill a spirit of solidarity and self-confidence in the women, and (b) a commitment to grassroots leadership as a means of strengthening and nourishing the dormant power of poor women.

7. It is preferable to make use of existing government programs whenever possible. Whether they exist in actual fact or only on paper they can be activated to serve the needs of poor women. The Forum proved this by implementing the "small borrowers" scheme and thus institutionalizing its benefits for a broader audience. In principle, existing programs should not be duplicated. However, there are times when it may be necessary to create parallel delivery systems to guarantee that established programs reach poor women.

8. An organization wanting to reach and benefit large numbers of poor women need not have a lot of money, educated staff or technical expertise. The success of the Forum is due primarily to four factors: (a) selection of one critical issue (credit), (b) utilization of local leadership, (c) organization of women around existing neighborhood ties, and (d) decentralized, participatory management. With this structure the WWF has not had problems in communicating messages or receiving feedback from its members.

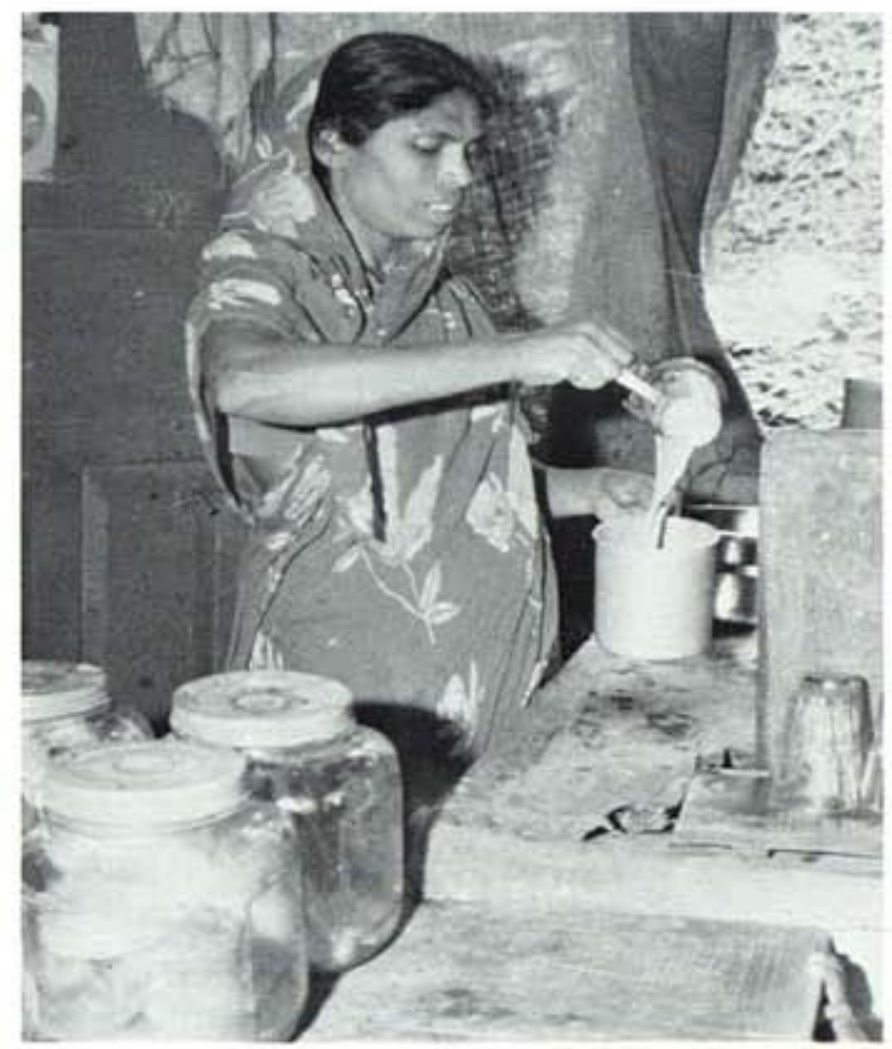


Appendix 1

\section{Organizational Chart}

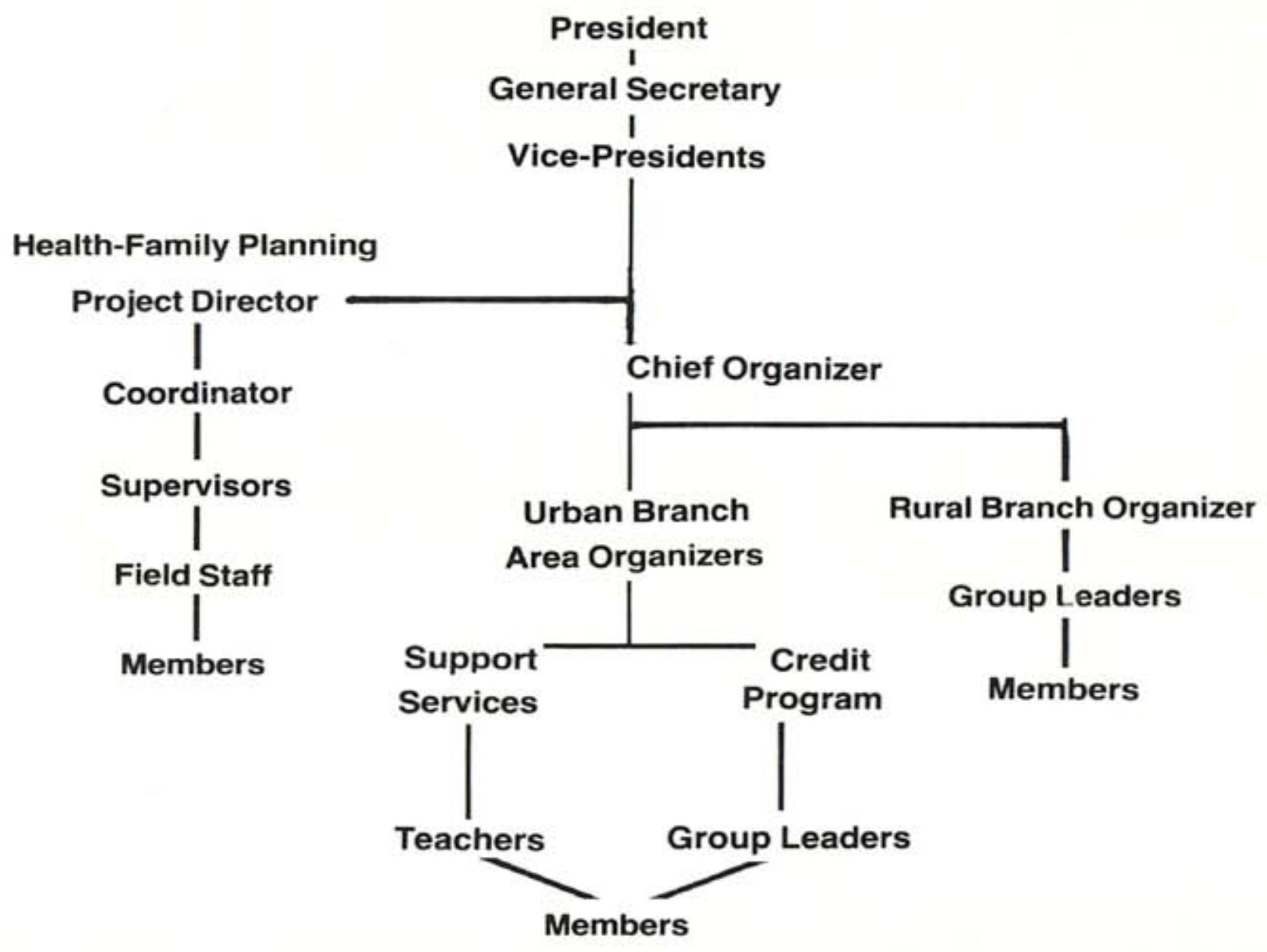

General Members - General Council. The general members, either full or associate, constitute the General Council of the Forum. They meet regularly (at least once a month) in their neighborhoods as individual groups; periodically in their locality with members of other groups; and annually in large public meetings or other functions. At individual and local meetings, the group leaders and area organizers try to instill the discipline and spread the ideology of the Forum. In the words of one area organizer, "We convene meetings to explain the rules and regulations of the Forum and to instill the discipline of regular attendance." At the same time, the general members are able to voice the problems and issues they face and would like to have addressed.

Group Leaders - Governing Body. The group leaders (currently 320) constitute the Governing Board of the Forum. They attend monthly coordination meetings at the Forum's office in which problems of individual groups and members are discussed and processed. They are expected to convey the gist of the discussion and the content of any decisions back to the general members. They also perform several key functions of the Forum: scrutiny of the loan applications of individual members and monthly collection and deposit of individual repayments. The group leaders work on a voluntary basis but are entitled to larger loans than the general members: 
Area Organizers - Field Staff. As the Forum membership grew, several group leaders who proved committed and skilled in organizing were promoted to supervise several groups in their locality. Their job is to meet the group leaders in their area at least once a week, to come into the WWF office twice a week, and to supervise the teachers of the creches or night schools. They also review loan applications recommended by group leaders, explain rules and regulations and assist the group leaders in cases of default.

Loan Officer, Chief Organizer - Administrative Staff. As the Forum's membership grew. and once the Forum decided to open its own Cooperative Credit Society, a chief organizer and loan officer were recruited (again from the ranks of the general members). The loan officer makes the final decision on all loan applications and on default. She also helps process loan applications. The chief organizer supervises and assists the area organizers in their work.

Office Holders - Standing Committee. The elected office holders include: three area organizers, one general secretary, two vice presidents and one president. They are the final decision-makers on all administrative and policy matters. The vice presidents and the general secretary also act as area organizers in their own localities. They periodically are deputed as members of spear-head teams when new branches of the Forum are opened.

Founder - President. Because of her special background and experience, the president has certain distinct and separate responsibilities. These include: (a) negotiation and liaison with banks, donor agencies, government and other organizations; (b) negotiating repayment schedules with the banks; (c) general administration; (d) fund raising; and (e) periodic group meetings and area visits.

\section{Appendix II}

\section{WWF Financing}

The majority of administrative costs of operating the Forum are met by an annual grant of Rs. 25,000 (U.S. \$2,834) from the Indo-German Social Service Society. The money pays for the salaries of the organizers, a clerk, typist, other administrative assistants, and for office supplies. A no-interest loan of Rs. 50,000 (U.S. \$5,700) from the same organization has been deposited as margin money in the nationalized banks, covering the borrowers' required contributions and guaranteeing the loans. Based on this guarantee, Rs. 200,000 (U.S. $\$ 22,700$ ) in loans can be extended to members.

The annual membership fee (currently Rs. 12 per year) should bring in Rs. 96,000 annually. However, as the women usually pay only at the start of a new bank loan - the dues being deducted from the top - the actual amount taken in each year is somewhat less. Funds collected as dues are used to meet additional administrative costs, to support recreation and other member activities, to provide transportation (especially for poor members to attend meetings), to cover the cost of coffee and snacks served at meetings, to aid women in urgent economic crises, and to underwrite anniversary celebrations and inaugural functions.

The monthly expenses of the Forum now average Rs. 14,000 (U.S. \$1,555). The Forum gets about $\$ 1,000$ per month from grants and another $\$ 300$ per month from membership fees. At present, WWF is running at a slight deficit, but only because it has not actively sought funding.

Outside support is primarily from private organizations such as: The Indo-German Social Service Society, the Family Planning Foundation of India, Appropriate Technology Int'.., Rabo Bank Netherlands, the Ford Foundation, Oxfam-America, and ICAR Lab-to-Land and $F A O$ for the rural program. 


\title{
Design: Ann Leonard
}

Typography: Village Type and Graphics

Photos: Marty Chen

Printing: Graphic Impressions, Inc.

We invite your comments and your ideas for projects which might be included in future editions of SEEDS. If you would like additional copies of this issue or would like to be included on the SEEDS mailing list, please write to:

\author{
Ann Leonard, Editor \\ SEEDS \\ P.O. Box 3923 \\ Grand Central Station \\ New York, New York 10163 U.S.A.
}




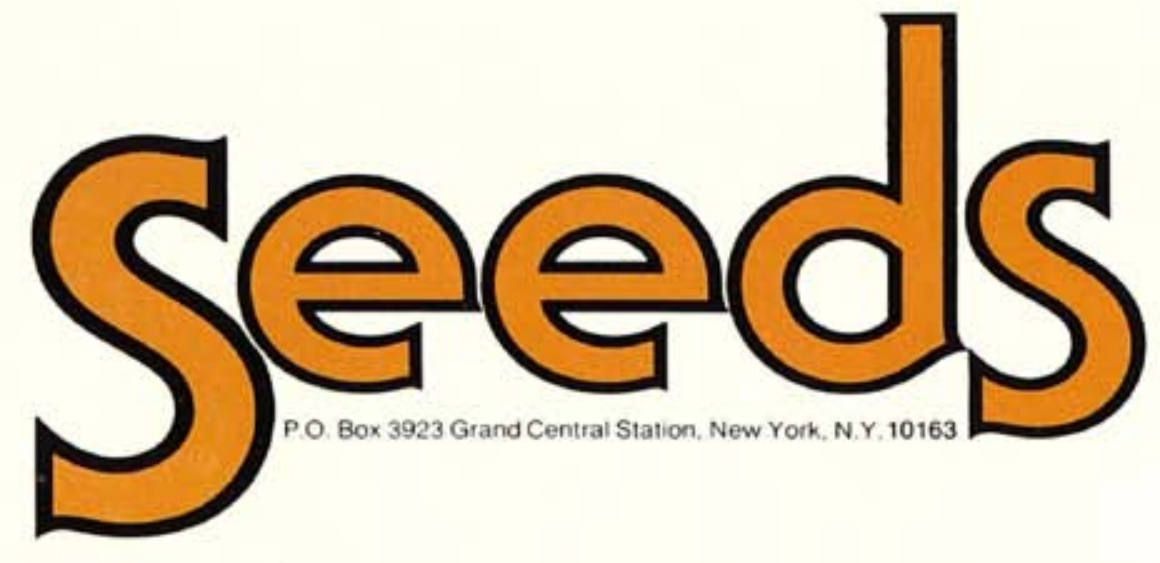

